\title{
Topical Solution Dosage Form
}

National Cancer Institute

\section{Source}

National Cancer Institute. Topical Solution Dosage Form. NCI Thesaurus. Code C64905.

A solution intended for administration to a body surface. 